\title{
First Report on the Diversity and Distribution of Parasitic Monogenoids (Platyhelminthes) From Catfishes (Siluriformes) in Arunachal Pradesh, India
}

\author{
Amit Tripathi ( $\square$ amit.tripathi@rgu.ac.in ) \\ University of Lucknow https://orcid.org/0000-0002-2751-4437 \\ Leki Wangchuk \\ Jawaharlal Nehru College \\ Dobium Narba \\ Dera Natung Government College \\ Chawan Matey \\ University of Lucknow
}

\section{Research Article}

Keywords: Arunachal Pradesh, diversity, first host record, monogenoids, new host record, Siluriformes

Posted Date: August 10th, 2021

DOI: https://doi.org/10.21203/rs.3.rs-775340/v1

License: (c) (i) This work is licensed under a Creative Commons Attribution 4.0 International License. Read Full License 


\section{Abstract}

Monogenoidea (Platyhelminthes), one of the largest groups of ectoparasitic metazoans worldwide, comprises over 10,000 nominal species distributed globally, many of which may represent a serious threat to their fish hosts in aquaculture conditions. The fish fauna of Arunachal Pradesh, India- a global hotspot of biodiversityis reasonably well-documented, with at least 213 known species (including 69 Siluriformes). These faunas are an essential resource for this tribal state's economy. In sharp contrast, information on parasitic monogenoids of fish from the region is extremely limited, with only nine species described to date. In this study, 21 species of catfishes were collected and examined with the aim of expanding the current knowledge of the diversity and distribution of monogenoid species from Arunachal Pradesh. 15 (62.5\%) of the 21 catfish species studied were infected with a total of 25 monogenoid species (11 previously described and 14 newly discovered in this study). Ten species of catfish were the first host records for new parasite species, while two species of catfish were new host records for previously known monogenoids. Arunachal Pradesh represents new geographic locality records for all 11 previously described parasite species, thus significantly expanding their distribution area from North and South India to extreme Northeast India. The patterns of parasite species richness in relation to three ecological traits (fish habitat, body size, and elevation) as well as host specificity across the 21 examined species of catfishes, the unique problem of too many parasite species in Wallago attu, and the future of parasitology in Arunachal Pradesh, India are discussed.

\section{Introduction}

Monogenoids (Platyhelminth) are one of the most conspicuous groups of fish parasites in the modern world. They are hugely diverse, with more than 7000 extant species distributed across the globe (Gibson et al. 2014) that fill a wide range of ecological niches from arthropods to molluscs, fishes, amphibians, reptiles, and even mammals (Roberts et al. 2009). These parasites primarily infect external surfaces and/or the gills of freshwater and marine fish. Upon finding a suitable host fish, these worms settle on the gills and start feeding on the host's blood (Hayward et al. 2007), epithelial cells, and/or mucus (Buchmann and Bresciani 2006). In addition to their impacts on the host's physiology, their feeding habits can provide an entry point for secondary diseases by breaking down the mucous layer covering the gill and skin epithelia (Grimes et al. 1985). This can result in fish population losses owing to mortality (typically among young fish and those kept in intense culture or captive) (Paperna et al. 1984; Rohde 1984,1993; Thoney and Hargis 1991). Monogenoids are the most host-specific of all fish parasites (Whittington et al. 2000). Therefore, they have been frequently employed as a valuable model for investigating biogeography and co-evolution (Boeger and Kritsky 2003) as well as indicators of host population migrations (Gusev 1976). They are also useful models for ecological (Rohde 1979 1984, 1994; Simkova et al. 2002) and evolutionary processes (Poulin 2002).

Arunachal Pradesh, India's far northeast state, is located at the crossroads of three major bio-geographical realms of the world: the Indian, Indo-Malayan, and Indo-Chinese. This one-of-a-kind location has facilitated a highly diversified biota with several endemic species. The state, identified as one of the world's most well-known hotspots of biodiversity (Chowdhery 1999), is a home to no fewer than 213 recorded freshwater fish species ( $21 \%$ of total freshwater fish in India), including 69 Siluriformes (more commonly known as catfishes) (Bagra et al. 2009). Catfishes are highly valued as food worldwide, and they are also growing more popular as sport fish and tropical aquarium fish (Nelson 2006). Arunachal Pradesh is no exception to this. These fish are vital to the 
state's economy (Government of Arunachal Pradesh 2021a), an essential part of local people's diets, as these people typically survive on natural resources (Tripathi 2011), and an integral part of the region's tribal culture, religion, and customs (Viswanath 2002; Gurumayum et al. 2006). To catch Bagarius spp. (vernacular name 'Ngone' in the Adi tribe), for example, the approval of the entire village is required.

Catfish, like any other group of fish, are vulnerable to parasitic infection, including monogenoids. Old World Siluriformes, for example, are known to harbour 272 monogenoid species, including 65 species from India alone (Lim et al. 2001). Unfortunately, the literature on the diversity and distribution of fish parasites from Arunachal Pradesh is very limited compared to similar literature on the diversity of fish in this region (Tripathi 2011). Presently, approximately 400 monogenoid species are known to live in Indian waters (Pandey and Agrawal 2008), with only nine species in Arunachal Pradesh (Wangchu et al. 2017; Tripathi et al. 2019). Of these nine species, only three have been described as infecting two species of catfish examined so far: Thaparocleidus motumensis and T. pterocryptisii [from Pterocryptis indicus (Datta, Barman, and Jayaram, 1987)] (Wangchu and Narba 2015), and Cornudiscoides bleekerai Agrawal and Vishwakarma, 1996 [from Mystus bleekeri (Day, 1877)] (Tripathi et al. 2019).

This highlights a massive knowledge gap in biodiversity studies on this group of fish parasites in Arunachal Pradesh. Therefore, we aimed to fill this void by characterising the fauna of parasitic monogenoids of the most common siluriform species in Arunachal Pradesh. Catfish comprising 21 species were collected and examined. Of them, 15 were found to host 25 species of monogenoids (14 new species and 11 previously described species). Detailed descriptions of the new species are underway in our laboratory and will be offered for publication separately. Meanwhile, this paper describes Arunachal Pradesh as a new geographic distribution record for all 11 previously described species, as well as 10 first host records for 14 new species and two new host records for three previously described monogenoid species.

The data set compiled here is the first on the diversity and distribution of parasitic monogenoids from catfishes in a biogeographical area that had previously been mostly ignored. The information provided here will be essential for the early detection, precise identification, and, therefore, the efficient management of fish diseases in Arunachal Pradesh.

\section{Materials And Methods}

\section{Study area and period}

The research was carried out in Arunachal Pradesh, India (29³0' N; 97³0’ E) from January 2015 to December 2018 (Fig. 1). Arunachal Pradesh has very rich water resources comprising following major river basins: Tawang, Kameng, Dikrong, Subansiri, Siang, Sisiri, Dibang, Lohit and Tirap (Government of Arunachal Pradesh 2021b). Rivers originating from these basins ultimately drain into the Brahmaputra River, which is the fifthlargest river in the world by average discharge (Government of Assam 2020). We collected catfish samples from 13 localities spanning seven out of nine major river basins. The altitudes (elevation above sea level) of sampling sites, as determined using the freely available Google Maps JavaScript API (DaftLogic 2018), were classified into three categories: low (<500 m), mid (500 m to $1000 \mathrm{~m})$, and high (>1000 m).

\section{Catfish sampling}


Twenty-one catfish species were captured with the help of indigenous fishing devices (see Chetry et al. 2012 for details). For any given host species, specimens were sampled at least twice across its sampling area to control for sampling effort. Some of these fish, with their flatworms, were immediately fixed in warm $\left(60^{\circ} \mathrm{C}\right) 4 \%$ formalin for later morphological examination. The name of the host species and the date of collection were recorded for

all specimens. Others were transported back to the laboratory live in aerated cans where they were maintained in glass aquaria until dissected-usually within one week of collection. These specimens were used to study live worms. The specific identity and common names of fish followed the keys provided by FishBase (Froese and Pauly 2018) and Jayaram (1999).

\section{Parasite sampling}

The gills of all sacrificed catfish were surgically removed, separated in Petri dishes with $0.9 \%$ saline, and examined under a stereomicroscope for monogenoids. When present, they were picked off the gills with fine needles and identified under a light microscope using the identification keys provided by Gusev (1976). The parasite specimens collected in formalin were temporarily mounted on a glass slide in glycerine and/or sodium dodecyl sulphate (Wong et al. 2006) so that their sclerotised body parts could be examined. Some of the specimens were mounted in Canada balsam after being dehydrated in an ascending series of ethanol $(70 \%$, $90 \%$, and $100 \%$ ) and cleared in xylene so to study their soft body parts.

\section{Results And Discussion}

Diversity of fish: A total of 21 species of catfishes from 15 genera and eight families were collected and checked for monogenoids (Table 1) (Fig. 1). Mystus and Glyptothorax had the highest diversity (three species each), followed by Batasio and Creteuchilolansis (two species each). The remaining genera had the least diversity (one species each). Bagridae was the most diverse family (six species), followed by Sisoridae (four species), Siluridae (three species), and Eristidae and Amblyceptidae (one species each).

\section{Patterns of parasite diversity}

The final host-parasite dataset included 25 parasite records from 21 host species from eight different families (Table 1). Of the 21 host species, 15 (62.5\%) were infected with 11 previously described species from four genera (Bifurcohaptor, Cornudiscoides, Mizelleus, and Thaparocleidus) and 14 new species from four genera (Bychowskyella, Cornudiscoides, Gyrodactylus, and Thaparocleidus) (Fig. 2). The remaining six catfish species were not infected, likely due to the relatively small numbers $(<5)$ of specimens from these species were collected. These six species were Creteuchiloglanis kamengensis (Jayaram, 1966), Creteuchiloglanis sp., Pachypterus atherinoides (Bloch, 1794), Heteropneustes fossilis (Bloch, 1794), Nangra assamensis (Sen and Biswas, 1994), and Olyra longicaudata (McClelland, 1842).

The identified parasite species belonged to six known genera (Bifurcohaptor, Bychowskyella, Cornudiscoides, Gyrodactylus, Thaparocleidus, and Mizelleus), two families (Dactylogyridae and Gyrodactylidae), two orders (Dactylogyridea and Gyrodactylidea), and one subclass (Polyonchoinea) of the class Monogenoidea.

Thaparocleidus was the most diverse genus (12 species; 48\%), followed by Cornudiscoides (four species; $16 \%$ ), Bychowskyella and Gyrodactylus (three species each; 12 \%), and Bifurcohaptor (two species; 8 \%) and Mizelleus (one species; 4 \%) (Fig. 3). Except for Cornudiscoides proximus and Bifurcohaptor indicus, which infected two 
hosts: Mystus dibrugarensis and Mystus tengara, other parasite species were restricted to one host (specialists). The infection levels ranged from 0 to 5 species of monogenoids (on Mystus dibrugarensis and Wallago attu). All species except Gyrodactylus sp. n. 3 (which infected the skin of $A$. arunachalensis) inhibited gills, confirming that the gills of fish species are the preferred biotope for Indian monogenoids.

In terms of heterogeneity, Bagridae was the most diverse family (four parasite genera), followed by Siluridae and Sisoridae (two parasite genera each), and Erithistidae and Amblyciptidae (one parasite genera each) (Fig. 4). Wallago attu and Mystus dibrugarensis had the highest numbers of monogenoid species (five parasite species each), followed by Pterocryptus indicus, Mystus bleekeri, Mystus tengara, and Ompok pabda (two parasite species each); the remaining nine hosts each had one monogenoid species (Fig. 2).

Only three Gyrodactylus species have been described from Indian catfishes: G. gusevi Dubey, Gupta and Agarwal 1990 and G. neonephrotus malmbergi Singh and Agrawal, 1994 both from Heteropneustes fossilis, and G. mizellei Dubey, Gupta and Agarwal 1990 from Mystus vittatus. Therefore, the record of three new Gyrodactylus species from catfishes of Arunachal Pradesh was a special finding (Table 1).

New host and geographic distribution records: Arunachal Pradesh represents a new geographical locality record for all 11 previously described parasite species (Table 1). This considerably expands their geographic distribution from North and South India to also include the country's far extreme northeastern corner. These species cover a range of more than $2000 \mathrm{~km}$. Two species of catfish represent new host records for previously known species of parasitic monogenoids-Ompok pabda (for Thaparocleidus malabaricus) and Mystus bleekeri (for Cornudiscoides agarwali) (Table 1). Ten species of catfish represent first host records for (new species of) parasitic monogenoids: Glyptothorax cavia, Glyptothorax mibangi, Glyptothorax dikrongensis, Pterocryptus indicus, Batasio batasio, Batasio fasciolatus, Gagata cenia, Mystus dibrugarensis, Pseudolaguvia viriosa, and Amblyceps arunachalensis (Table 1).

Interestingly, we found new species of monogenoid only in catfishes that can be found only in Arunachal Pradesh and/or other parts of Northeast India and, therefore, had never been sampled before. Conversely, we found new geographic records for-but no new species of-monogenoids when we screened fish that had been sampled before in other parts of the country. The lone exception to this pattern was Mystus bleekeri. This species had been studied for monogenoids and was known to harbour six monogenoid species: T. pusillus (Gusev, 1976) Lim, 1996), C. bleekerai Agrawal and Vishwakarma, 1996, C. geminus Gusev, 1976, C. gusevi Agrawal and Vishwakarma, 1996, C. susanae Agrawal and Vishwakarma 1996, and C. tukarami Agrawal and Vishwakarma, 1996 (see Pandey and Agarwal 2008). In the present study, we found two species from $M$. bleekeri (Cornodiscoides sp. n. 1 and Cornudiscoides agarwali Agrawal and Vishwakarma, 1996) but, surprisingly, found none of the six previously identified species mentioned above. Tripathi et al. (2019) reviewed this problem in detail and concluded that earlier authors probably confused M. vittatus with M. bleekeri. Examining the samples of $M$. vittatus and finding thereon worms described from $M$. bleekeri would confirm this assumption.

\section{Impact of host habitat}

In this study, all infected catfish were demersal except for Pterocryptis indicus and Glyptothorax cavia, which were benthopelagic (Table 1) (see Froese and Pauly, 2018). A comparative analysis of the parasite species' richness across 15 catfish shows that both benthopelagic and demersal catfishes were infected with 
monogenoids. However, demersal fish were infected with 21 parasite species, while benthopelagic fish were infected with only three parasite species. This is likely due to sampling bias, as the demersal fish outnumbered the benthopelagic fish in our sample. So, in a broad sense, our results are inconsistent with previous studies; for example, Luque et al. (2004) reported that host depth range had no effect on ectoparasite species richness.

\section{Impact of host body size}

The size of the host body is an important ecological determinant of parasite species richness (Morand 2015). We observed heterogeneous results concerning the correlation between body size and parasite species richness. $W$. attu had the most monogenoid species (five), possibly due to its large size (total length of up to $240 \mathrm{~cm}$ ) (Froese and Pauly 2018), which provides more available niches for parasitic colonisation (see Sasal et al. 1997). Alternative justifications might also explain this pattern-for example, since $W$. attu is a large potamodromous fish covering an extensive geographical range, it is exposed to more parasite species than other catfishes (see Morand 2000). The case of M. dibrugarensis, on the other hand, contradicts the notion that the larger the host size, the higher the parasite richness. M. dibrugarensis is a small silurid (total length of up to $9.50 \mathrm{~cm}$ ) (Bailung and Biswas 2015), yet it harboured as many different species as $W$. attu (five) (Table 1).

Impact of elevational gradient: A major issue in modern parasite ecology is the current lack of knowledge of the factors that influence the diversity and distribution of parasites-and, consequently, disease outbreaks (Hawkins et al. 2003). Unfortunately, the main drivers of parasite diversity are still poorly understood (Poulin and Morand 2004). The data, though preliminary, indicates a negative correlation between the species richness of parasitic monogenoids and the $1747.60-\mathrm{m}$ elevational gradient (Table 2) (Fig. 5). Lower altitudes were home to $83.33 \%$ of the specific diversity of monogenoids, while mid altitudes were home to $16.66 \%$ of the specific diversity. At high altitudes, no parasites were found. Water temperature is one of the most important environmental variables influencing the distribution of monogenoids, with higher water temperatures increasing their reproduction rate and population growth (Jansen and Bakke 1991; Anderson and Buchmann 1998). We suggest that the observed general decrease in monogenoid species richness along an altitudinal gradient is caused by the corresponding decrease in water temperature because temperature is inversely related to elevation.

\section{Host specificity of monogenoids}

The rivers Ganges (in north India) and Brahmaputra (in northeast India) originate from glaciers on the southern and northern slopes of the Himalayan mountains, respectively. They take different paths before joining in the Bengal Basin and debouching to the Bay of Bengal (Subramanian and Ramanathan 1996, as cited in Kuehl et al., 2005). Then, how did ten monogenoid species previously described from the north India and south Indian river waters end up in the basins of the River Brahmaputra in Arunachal Pradesh even though these basins are not connected in India?

In general, the distribution of parasites follows the distribution of their hosts (Rohde 1993; Poulin 1998). This seems to hold especially true for monogenoids, which mandatorily depend on their fish hosts to complete their life cycle. Existing explanations for how fish (and their parasites) colonise unconnected water bodies involve either dispersal or vicariance-vicariance-based scenarios are generally favoured (see, for e.g., Berra 2001, Zanata et al. 2005). In either case, the presence of North and South Indian species of host fish and their monogenoids in Arunachal waters indicates that the host fish must have brought their parasites with them as they travelled from North or South Indian waters to the Brahmaputra River system of the Arunachal Pradesh 
region. Moreover, these worms did not engage in host switching (i.e., they remained on their original hosts and did not colonise new potential host species). Thus, our observation that previously non-sampled catfishes harboured new monogenoid species while previously sampled catfishes harboured already known monogenoid species supports the prediction of Whittington et al. (2000) that the monogenoids are probably the most hostspecific of all fish parasites.

Variety of species on Wallago attu: Wallago attu presented a unique problem. This fish-sometimes known as the freshwater shark-is a commercially and recreationally important catfish native to Indian subcontinent (Froese and Pauly 2018). The species has been listed as endangered (Mijkherjee et al. 2002) and vulnerable (Ng et al. 2019) because of a rapid population declines throughout its range due to their over-exploitation for food, ornamental and recreational purposes, pollution, and environmental degradation, among other reasons. The systematics of the monogenoids of this host fish have become unmanageable due to new species descriptions over the last three decades. To date, approximately 40 nominal monogenoid species from 10 genera have been recorded from W. attu (Lim et al. 2001; Pandey and Agarwal 2008). Much of the information on these parasite taxa has been published in obscure, often inaccessible local journals, thus giving rise to numerous nomenclatural synonymies in the literature. Not surprisingly, our sampling efforts from $W$. attu in Arunachal Pradesh consistently yielded only five species: Thaparoleidus gomtius, Thaparocleidus yogendraii, Thaparocleidus indicus, Thaparoleidus sudhakari, and Mizelleus indicus. While we have no intention of discrediting the observations of previous authors who described these species, we also would not be surprised if many of the previously described species are spurious. In any case, the taxonomy of monogenoids from threatened $W$. attu is in a state of considerable confusion and instability. The parasites may have a negative impact on threatened hosts, in part because they can accelerate severe population declines (De Castro and Bolker 2005; Blehert et al. 2009) and, as a result, the extinction risk of their host species (Altizer 2007; Heard et al. 2013). Thus, a precise validation of the taxonomic assignments of monogenoids from $W$. attu is required, particularly based on critical evaluations and DNA-based taxonomy.

Missing parasite groups: So far, the following seven monogenoid genera have been identified from freshwater Indian Siluriformes: Ancylodiscoides (Yamaguti, 1937), Bifurcohaptor (Jain, 1958), Bychowskyella (Akhmerov, 1952), Cornudiscoides (Kulkarni, 1969), Mizelleus (Jain, 1957) Quadriacanthus (Paperna, 1961), and Thaparocleidus (Jain, 1952) (Pandey and Agarwal 2008). Of these species, we failed to find only two: Ancylodiscoides and Quadriacanthus. Since the present study sampled only 21 out of 69 Siluriformes, the absence of these two genera could simply be due to the small sample size.

Future of parasitological research in Arunachal Pradesh: Arunachal Pradesh has a relatively short history of modernisation, having begun only after India's independence in 1947 (Planning Commission of India 2018). The state has just one university and no research centres or laboratories for studying parasitology. Consequently, the fish parasites inhabiting this area, including monogenoids, have remained largely unknown. In fact, in 2011, we were the first group of researchers to study fish parasites of this region. Two of our previous (unpublished) studies, which were conducted as parts of projects sponsored by the Government of India [UGC; 39-603/2010 (SR) and DST; SR/SO/AS-56/2011], revealed about 87 new species of parasitic monogenoids from 45 species of fish representing 31 genera, 13 families, and six orders. This confirms Arunachal Pradesh's status as a hotspot for fish parasites. Over the last couple of years, a few Arunachali students have developed an interest in fish parasites, partly due to the motivation provided by one of us (AT) and partly due to the growing recognition of the relevance of parasitology in the fisheries and aquaculture sector, which represents the most dominant 
form of self-employment in Arunachal Pradesh. If these students can secure a permanent position at a state college or university, they can begin a new tradition in systematic work on parasites in Arunachal Pradesh.

\section{Conclusions}

With ten first host records, two new host records, and Arunachal Pradesh a new geographic locality record for 10 parasite species, the present study considerably increase the current knowledge of the diversity and distribution of the monogenoids that infect Siluriforme fishes in Arunachal Pradesh, India. Understanding and monitoring the parasitological health of fish fauna of this region will be crucial to their production, management and conservation. The knowledge presented here will assist future comparative studies on the helminth fauna of the same host species in other areas of India and Asia. However, the true diversity of the monogenoids of Silurifomes in Arunachal Pradesh is still unknown, as this study screened only about $30 \%$ (21 of 69) of the catfish species that inhabit this region.

\section{Declarations}

\section{Author contributions}

LW and AT designed the study. LW, DN, and CM collected the samples and performed morphological studies and data analysis. AT drafted the final version of the article with the help of all authors.

\section{Ethics}

The fish samples were sacrificed in a humane manner, in accordance with the procedures and protocols approved by Ethical Committee for Research on Laboratory Animals, Rajiv Gandhi University, Arunachal Pradesh.

\section{Acknowledgements}

We thank Professor Debangshu N. Das, Rajiv Gandhi University, Arunachal Pradesh for helping with the taxonomic identification of catfishes collected for this study. We also thank our postgraduate and PhD students (especially Achom Darshan, Dilip Chetry, Sangeeta Biswas, Nguli Dabi, Michi Yassa, Likha Rema, Ome Tayeng, Jeena Gollo, Karmu Monpa) whose contributions were fundamental to our sampling efforts over the years. AT gratefully acknowledges financial support received from the University Grant Commission, Government of India [39-603/2010 (SR)] and the Department of Science and Technology, Government of India [SR/S0/AS-56/2011]. This paper is based on the PhD thesis of LW at Rajiv Gandhi University, Arunachal Pradesh, India.

\section{References}

1. Altizer S, Nunn CL, Lindenfors $P$ (2007) Do threatened fish have fewer hosts: A comparative study in primates. J Anim Ecol 6:304-314. https://doi.org/10.1111/j.1365-2656.2007.01214.x

2. Anderson PS, Buchmann K (1998) Temperature dependent population growth of Gyrodactylus derjavini on rainbow trout, Oncorhynchus mykiss. J Helminthol 72:9-14 https://doi.org/10.1017/s0022149x00000900.

3. Bagra K, Kadu K, Sharma KN, Laskar BA, Sarkar UA, Das DN (2009) Ichthyological survey and review of the checklist of fish fauna of Arunachal Pradesh, India. Check List 5:330-350 https://doi.org/10.15560/5.2.330 
4. Bailung B, Biswas SP (2015) New description of a Bagrid Catfish Mystus dibrugarensis (Chaudhuri, 1913) from Dihing river of Upper Assam. Int J Fish Aquat Stud 2:204-206

5. Berra TM (2001) Freshwater Fish Distribution. Academic Press, USA

6. Blehert DS et al. Hicks AC, Behr M, Meteyer CU, Berlowski-Zier BM, Buckles EL, Coleman JTH, Darling SR, Gargas A, Niver R, Okoniewski JC, Rudd RJ, Stone WB (2009)

7. Bat white-nose syndrome: an emerging fungal pathogen. Science 323:227. https://doi.org/10.1126/science.1163874

8. Boeger W, Kritsky DC (2003) Parasites, fossils and geologic history: Historical biogeography of the South American freshwater croakers, Plagioscion spp. (Teleostei, Sciaenidae). Zool Scr 32:3-11. https://doi.org/10.1046/j.1463-6409.2003.00109.x

9. Buchmann K, Bresciani J (2006) Monogenea (Phylum Platyhelminthes). In: Woo PTK (ed.) Fish diseases and disorders. Protozoan and metazoan infections, vol. 1. CAB International, Wallingford. pp 297344. https://doi.org/10.1079/9780851990156.0297

10. Bush AO, Lafferty KD, Lotz JM, Shostak AW (1997) Parasitology meets ecology on its own terms: Margolis et al. revisited. J Parasitol 83:575-583. https://doi.org/10.2307/3284227

11. Chetry DB, Narba D, Tripathi A (2012) Traditional fishing methods in Arunachal Pradesh. Pp 41-44. In A. Tripathi (Ed.) Proceedings of the 1st National Symposium on Fish Parasites, Helminthological Society of India, March 19-20, 2012. Itanagar, India.

12. Chowdhery HJ (1999) Floristic diversity and conservation strategies in India, BSI, Kolkata.

13. DaftLogic. Google Maps Find Attitude. Online: https://www.daftlogic.com/sandbox-google-maps-findaltitude.htm (accessed on 10/02/2017)

14. De Castro F, Bolker B ( 2005) Mechanisms of disease-induced extinction. Ecol Lett 8:117-126. https://doi.org/10.1111/j.1461-0248.2004.00693.x

15. Desdevises $Y$, Morand S, Legendre $P$ (2002) Evolution and determinants of host specificity in the genus Lamellodiscus (Monogenea). Biol J Linn Soc Lond 77:431-443. https://doi.org/10.1046/j.10958312.2002.00114.x

16. Froese R, Pauly D Editors (2018) FishBase. World Wide Web electronic publication. www.fishbase.org $(02 / 2018)$

17. Gibson D, Rodney AB, David H et al. (2014) Fauna Europaea: Helminths (Animal Parasitic) Biodivers Data J.e1060. https://doi.org/10.3897/BDJ.2.e1060

18. Government of Arunachal Pradesh (2021a) Department of Fisheries. Retrieved at http://meenarun.nic.in/twelvefyp.html

19. Government of Arunachal Pradesh (2021b) Official State Portal. Retrieved at https://www.arunachalpradesh.gov.in/know-arunachal/

20. Government of Assam (2020) River system of Assam. Retrieved at https://waterresources.assam.gov.in/portlet-innerpage/brahmaputra-river-system

21. Grimes DJ, Gruber SH, May EB (1985) Experimental infection of lemon sharks, Negaprion brevirostris (Poey), with Vibrio species. J Fish Dis 8:173-180. https://doi.org/10.1111/j.13652761.1985.tb01212.x 
22. Gurumayum SD, Devi GA, Nandeesha MC (2006) Women's participation in fisheries activities in Manipur Valley in India with traditional fish-based beliefs and customs. In: Poo PS, Hall SJ, Williams MJ (eds) Global symposium on gender and fisheries. 7th Asian Fisheries Forum 1- 4 Dec 2004 World Fish Centre, Penang, Malaysia, pp 149-158

23. Gusev AV (1976) Freshwater Indian monogenoidea: Principles of systematics, analysis of the world faunas and their evolution. Indian J Helminthol 25-26:1-241

24. Hawkins BA, Field R, Cornell H V, Currie DJ, Guegan JF, Kaufman DM, Kerr JT, Mittelbach GG, Oberdorff T, O'Brien EM, Porter EE, Turner JRG (2003) Energy, water, and broad-scale geographic patterns of species richness. Ecology 84:3105-3117. https://doi.org/10.1890/03-8006

25. Hayward CJ, Bott NJ, Naoki I, Iwashita M, Okihiro M, Nowak BF (2007) Three species of parasites emerging on the gills of mulloway, Argyrosomus japonicus (Temminck and Schlegel, 1843), cultured in Australia. Aquaculture 265:27-40. https://doi.org/10.1016/j.aquaculture.2007.02.004

26. Heard MJ, Smith KF, Ripp KJ, Berger M, Chen J, Dittmeier J, Goter M, McGarvey ST, Ryan E. (2013) The threat of disease increases as species move toward extinction. Conserv Biol 27:1378-1388. https://doi.org/10.1111/cobi.12143

27. Hossain MY (2014) Threatened fishes of the world: (Bloch, 1794) (Siluriformes: Bagridae). Croatian Journal of Fisheries 72: 183-185. https://doi.org/10.14798/72.4.770

28. Jansen PA, Bakke TA (1991) Temperature-dependent reproduction and survival of GyrodactylussalarisMalmberg, 1957 (Platyhelminthes: Monogenea) on Atlantic salmon (Salmo salarL.). Parasitology 102:105-112. https://doi.org/10.1017/S0031182000060406

29. Jayaram KC, Sanyal A (2003) A taxonomic revision of the fishes of the genus Mystus scopoli. (Family: Bagridae) records of the zoological survey of India. Zoological Survey of India 207:1-141

30. Kritsky DC, Boeger WA, Thatcher VE (1985) Neotropical monogenea. 7. Parasites of the pirarucu, Arapaima gigas (Cuvier), with descriptions of two new species and redescripton of Dawestrema cycloancistrium Price and Nowlin, 1967 (Dactylogyridae: Ancyrocephalinae). Proc Biol Soc Wash 98:321-31

31. Kuehl SA, Allison MA, Goodbred SL, Kudrass H (2005) The Ganges-Brahmaputra Delta. In: Giosan L. and Bhattacharya J.P. (ed) River Deltas-Concepts, Models and Examples, SEPM (Society for Sedimentary Geology) Special Publication pp 83, pp 413-434

32. Lim LHS, Timofeeva TA, Gibson DI (2001) Dactylogyridean monogeneans of the siluriform fishes of the Old World. Syst Parasitol 50:159-197

33. Luque JL, Mouillot D, Poulin R (2004) Parasite biodiversity and its determinants in coastal marine teleost fishes of Brazil. Parasitology 128:671-682

34. Mirza MQ, Warrick RA, Ericksen NJ, Kenny GJ (1998) Trends and persistence in precipitation in the Ganges, Brahmaputra and Meghna river basins, Hydrol Sci J 43:845-858.

https://doi.org/10.1080/02626669809492182

35. Mijkherjee M, Praharaj A, Das S (2002) Conservation of endangered fish stocks through artificial propagation and larval rearing technique in West Bengal, India. Aquac Asia 7:8-11

36. Morand S (2000) Wormy world: comparative tests of theoretical hypotheses on parasite species richness. In: Poulin R, Morand S, Skorping A (eds.) Evolutionary Biology of Host-Parasite Relationships: Theory Meets Reality, Elsevier, Amsterdam, pp 63-79 
37. Morand S (2015) (macro-) Evolutionary ecology of parasite diversity: From determinants of parasite species richness to host diversification. Int J Parasitol: Parasites Wildl 4:80-

87. https://doi.org/10.1016/j.ijppaw.2015.01.001

38. Nelson SJ (2006) Fishes of the world. Fourth edition, John Wiley \& Sons, New Jersey.

39. Ng HH, de AlwisGoonatilake S, Fernado M, Kotagama O (2019) Wallago attu. The IUCN Red List of Threatened Species 2019: e.T166468A60586371. https://dx.doi.org/10.2305/IUCN.UK.2019-

3.RLTS.T166468A60586371.en. Downloaded on 20 April 2020.

40. Pandey KC, Agrawal N (2008) An Encyclopedia of Indian Monogenoidea. Vitasta Publishing Pvt. Ltd., New Delhi

41. Paperna I, Diamant A, Overstreet RM (1984) Monogenean infestations and mortality in wild and cultured Red Sea fishes. Helgolander Meeresunters 37:445-462. https://doi.org/10.1007/BF01989323

42. Plamoottil M (2017) Taxonomic notes on Mystus species of northern Kerala. J Aquac Res Dev 8:495. https://doi.org/10.4172/2155-9546.1000495

43. Planning commission of India (2018) State development reports. Available at http://planningcommission.gov.in/plans/stateplan/sdr/sdr_ap1909.pdf

44. Poulin R (1998) Evolutionary ecology of parasites: From individuals to communities. Chapman and Hall, London

45. Poulin R (2002) The evolution of monogenean diversity. Int J Parasitol 32:245-254. https://doi.org/10.1016/S0020-7519(01)00329-0

46. Poulin R (2004) Parasite species richness in New Zealand fishes: a grossly underestimated component of biodiversity. Divers Distrib 10:31-37. https://doi.org/10.1111/j.1472-4642.2004.00053.x

47. Poulin R, Morand S (2004) Parasite Biodiversity. Washington (DC): Smithsonian Books

48. Roberts LS, Schmidt GD, Janovy JJr. (2009) Gerald D. Schmidt and Larry S. Roberts' foundations of parasitology. 8th edition. McGraw-Hill Higher Education, Boston, USA

49. Rohde K (1979) A critical evalution of intrinsic and extrinsic factors responsible for niche restriction in parasites. Am Nat 114:648-671. https://doi.org/10.1086/283514

50. Rohde K (1984) Helminth Diseases of Marine Fishes. In Diseases of Marine Animals, vol. IV (ed. O. Kinne). Biologische Anstalt Helgoland 193-320

51. Rohde K (1993) Ecology of marine parasites: An introduction to marine parasitology. 2nd edition. Cab International, Wallingford, Oxon, UK

52. Rohde K (1994) Niche restriction in parasites-proximate and ultimate causes. Parasitology 109:69-84. https://doi.org/10.1017/S0031182000085097

53. Sasalli P, Morand S, Guegan JF (1997) Determinants of parasite species richness in Mediterranean marine fishes. Mar Ecol Prog Ser 149:61-71

54. Simkova A, Ondrackova M, Gelnar M, Morand S (2002) Morphology and coexistence of congeneric ectoparasite species: reinforcement of reproductive isolation? Biol J Linn Soc Lond 76:125-135. https://doi.org/10.1111/j.1095-8312.2002.tb01719.x

55. Singh SS, Chingakham BS, Gusheinzed W (2013) Karyotype Analysis of the New Catfish Mystus ngasep (Siluriformes: Bagridae) from Manipur, India. Turkish J Fish Aquat Sci 13:179-185.

https://doi.org/10.4194/1303-2712-V13_1_21

Page $11 / 20$ 
56. Subramanian V, Ramanathan AL (1996) Nature of sediment load in the Ganges-Brahmaputra river systems in India. In: Milliman JD and Haq BU (eds) Sea-Level Rise and Coastal Subsidence: Kluwer Academic Publishers, Dordrecht, Netherlands pp 151-168

57. Thompson JD, Higgins DG, Gibson TJ (1994) CLUSTAL W: improving the sensitivity of progressive multiple sequence alignment through sequence weighting, position-specific gap penalties and weight matrix choice. Nucleic Acids Res 22:467380. https://doi.org/10.1093/nar/22.22.4673

58. Thoney DA, Hargis WHJ (1991) Monogenea (Platyhelminthes) as hazards for fish in confinement. Annu Rev Fish Dis 1:133-153. https://doi.org/10.1016/0959-8030(91)90027-H

59. Tripathi A (2011) Helminth richness in Arunachal Pradesh fishes: A forgotten component of biodiversity. J Biosci 36:559-561. https://doi.org/10.1007/s12038-011-9088-z

60. Tripathi A (2014) The invasive potential of parasitic monogenoids (Platyhelminthes) via the aquarium fish trade: An appraisal with special reference to India. Rev Aquac 6:147-161. https://doi.org/10.1111/raq.12035

61. Tripathi A, Wangchu L, Trivedi AK (2019) Prevalence and intensity of Cornudiscoides agarwali (Monogenoidea) on the gills of Day's Mystus (Mystus bleekeri) in relation to some ecological and biological factors from Arunachal Pradesh, India. Helminthologia 56:141-150. https://doi.org/10.2478/helm-20190005

62. Tu X, Ling F, Huang AG, Wang GX (2015) An infection of Gyrodactylus kobayashii Hukuda, 1940 (Monogenea) associated with the mortality of gold fish (Carassius auratus) from central China. Parasitol Res 114:737-745. https://doi.org/10.1007/s00436-014-4241-x

63. Vishwanath W (2002) Fishes of North East India. A field guide to species identification. National Agricultural Technology Project. Imphal: Manipur University.

64. Wangchu L, Narba D (2015) A preliminary survey of parasitic monogenoids (Platyhelminthes) of some important catfish (Teleostei: Siluriformes) in Arunachal Pradesh, with description of two new species of Thaparocleidus Jain, 1952. In: Tripathi A (ed) Proceeding of the $2^{\text {nd }}$ National Symposium on Fish Parasites, 43-49. Itanagar, November 23-24, 2015. The Helminthological Society of India.

65. Wangchu L, Narba D, Yassa M, Tripathi A (2017) Dactylogyrus barnaesp. n. (Platyhelminthes: Monogenoidea) infecting gills of Barilius barna Hamilton, 1822 (Pisces: Cyprinidae) from a global biodiversity hotspot-Arunachal Pradesh (India) Vet World 10:505-509. https://doi.org/10.14202/vetworld.2017.505-509

66. Whittington ID (1988) Diversity 'down under': monogeneans in the Antipodes (Australia) with a prediction of monogenean biodiversity worldwide. Int J Parasitol 28:1481-1493. https://doi.org/10.1016/S00207519(98)00064-2

67. Whittington ID, Cribb BW, Hamwood TE, Halliday J (2000) Host-specificity of monogenean (platyhelminth) parasites: a role for anterior adhesive areas? Int J Parasitol 30:305-320.

68. Wong WL, Tan WB, Lim LHS (2006) Sodium dodecyl sulphate as a rapid clearing agent for studying the hard parts of monogeneans and nematodes. J Helminthol 80:87-90. https://doi.org/10.1079/JOH2005320

69. Zanata AM, Vari RP (2005) The family Alestidae (Ostariophysi, Characiformes): a phylogenetic analysis of a trans-Atlantic clade. Zool J Linnean Soc 145:1-144. https://doi.org/10.1111/j.1096-3642.2005.00183.x 


\section{Tables}

Page 13/20 
Table 1

Host-parasite datasheet for monogenoids identified from catfishes examined in Arunachal Pradesh

\begin{tabular}{|lllll|}
\hline $\begin{array}{l}\text { S. Fo. } \\
\text { Nish sampled }\end{array}$ & $\begin{array}{l}\text { Sampling } \\
\text { site } \\
\text { (Habitat) }\end{array}$ & $\begin{array}{l}\text { Parasitism } \\
\text { (River basin, } \\
\text { District) }\end{array}$ & Parasite species & \\
\cline { 3 - 4 } & & New species & $\begin{array}{l}\text { Previously } \\
\text { known species }\end{array}$ & $\begin{array}{l}\text { First/New } \\
\text { host } \\
\text { record }\end{array}$ \\
\hline $\begin{array}{l}\text { Family: } \\
\text { Amblycipitidae }\end{array}$ & & & First \\
$\begin{array}{l}\text { Amblyceps } \\
\text { arunachalensis } \\
\text { (Nath and Dey, } \\
\text { 1989) }\end{array}$ & $\begin{array}{l}\text { Senki } \\
\text { (Papumpare) }\end{array}$ & + ive & $\begin{array}{l}\text { Gyrodactylus } \\
\text { sp.n. 3 }\end{array}$ & \\
(Demersal) & Tirap (Tirap) & & \\
\end{tabular}

Family: Bagridae

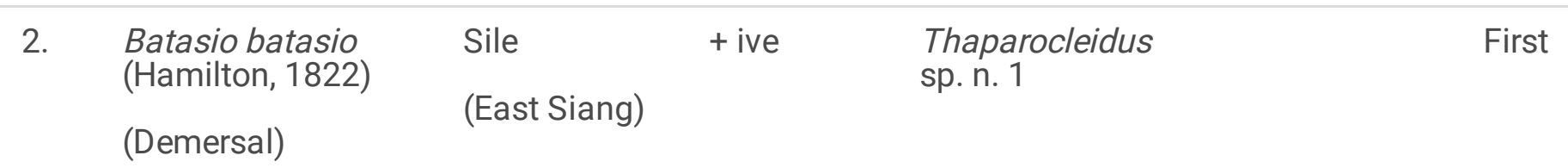
3. Batasio fasciolatus Motum +ive Thaparocleidus First
$(\mathrm{Ng}, 2006) \quad$ sp. n. 2
(East Siang)

(Demersal)
4. Mystus bleekeri Dikrong + ive Cornodiscoides Cornudiscoidea New

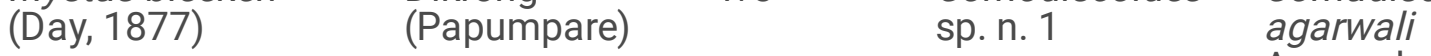
Agarwal and
(Demersal) Vishwakarma,
1996
5. Mystus Dikrong + ive Cornodiscoides Cornudiscoidea First
$\begin{array}{lll}\text { dibrugarensis } & \text { (Papumpare) } & \text { sp. n. } 2\end{array}$
(Chaudhuri, 1913) Gusev, 1976
(Demersal)
Gyrodactylus
sp. n. 2
Thaparocleidus 1958
sp. n. 4

\begin{tabular}{|c|c|c|}
\hline 6. & $\begin{array}{l}\text { Mystus tengara } \\
\text { (Hamilton, 1822) } \\
\text { (Demersal) }\end{array}$ & $\begin{array}{l}\text { Sejosa } \\
\text { (East } \\
\text { Kameng) }\end{array}$ \\
\hline 7. & $\begin{array}{l}\text { Sperata aor } \\
\text { (Hamilton, 1822) } \\
\text { (Demersal) }\end{array}$ & $\begin{array}{l}\text { Dikrong } \\
\text { (Papumpare) }\end{array}$ \\
\hline
\end{tabular}




\begin{tabular}{|c|c|c|c|c|c|c|}
\hline \multirow{2}{*}{$\begin{array}{l}\text { S. } \\
\text { No. }\end{array}$} & \multirow{2}{*}{$\begin{array}{l}\text { Fish sampled } \\
\text { (Habitat) }\end{array}$} & \multirow{2}{*}{$\begin{array}{l}\text { Sampling } \\
\text { site } \\
\text { (River basin, } \\
\text { District) }\end{array}$} & \multirow[t]{2}{*}{ Parasitism } & \multicolumn{3}{|l|}{ Parasite species } \\
\hline & & & & New species & $\begin{array}{l}\text { Previously } \\
\text { known species }\end{array}$ & $\begin{array}{l}\text { First/New } \\
\text { host } \\
\text { record }\end{array}$ \\
\hline \multirow[t]{3}{*}{8.} & $\begin{array}{l}\text { Pseudolaguvia } \\
\text { viriosa (Ng \& } \\
\text { Tamang, 2012) }\end{array}$ & $\begin{array}{l}\text { Senki } \\
\text { (Papumpare) }\end{array}$ & + ive & $\begin{array}{l}\text { Gyrodactylus } \\
\text { sp. n. } 1\end{array}$ & & First \\
\hline & (Demersal) & & & & & \\
\hline & $\begin{array}{l}\text { Family: } \\
\text { Heteropneustidae }\end{array}$ & & & & & \\
\hline \multirow[t]{3}{*}{9.} & $\begin{array}{l}\text { Heteropneusteus } \\
\text { fossilis (Bloch, } \\
1794 \text { ) }\end{array}$ & $\begin{array}{l}\text { Motum (East } \\
\text { Siang) }\end{array}$ & - ive & - & & \\
\hline & $\begin{array}{l}\text { Heteropneusteus } \\
\text { fossilis }\end{array}$ & & & & & \\
\hline & Family: Siluridae & & & & & \\
\hline \multirow[t]{2}{*}{10.} & $\begin{array}{l}\text { Ompok pabda } \\
\text { Hamilton, 1822) } \\
\text { (Demersal) }\end{array}$ & $\begin{array}{l}\text { Dibang } \\
\text { (Lower } \\
\text { Dibang } \\
\text { valley) }\end{array}$ & + ive & & $\begin{array}{l}\text { Thaparocleidus } \\
\text { octotylus } \\
\text { (Kulkarni, } \\
\text { 1969) Lim, } \\
1996\end{array}$ & New \\
\hline & & & & & $\begin{array}{l}\text { Thaparocleidus } \\
\text { malabaricus } \\
\text { (Gusev, 1976) } \\
\text { Lim } 1996\end{array}$ & \\
\hline \multirow[t]{3}{*}{11.} & $\begin{array}{l}\text { Pterocryptus } \\
\text { indicus (Datta, }\end{array}$ & $\begin{array}{l}\text { Dali (West } \\
\text { Siang) }\end{array}$ & + ive & $\begin{array}{l}\text { Thaparocleidus } \\
\text { motumensis }\end{array}$ & & First \\
\hline & Jayaram, 1987) & Pasighat & & Narba 2015 & & \\
\hline & (Benthopelagic) & Tirap (Tirap) & & $\begin{array}{l}\text { Thaparocleidus } \\
\text { pterocryptissi } \\
\text { Wangchu and } \\
\text { Narba } 2015\end{array}$ & & \\
\hline
\end{tabular}




\begin{tabular}{|c|c|c|c|c|c|c|}
\hline \multirow{2}{*}{$\begin{array}{l}\text { S. } \\
\text { No. }\end{array}$} & \multirow{2}{*}{$\begin{array}{l}\text { Fish sampled } \\
\text { (Habitat) }\end{array}$} & \multirow{2}{*}{$\begin{array}{l}\text { Sampling } \\
\text { site } \\
\text { (River basin, } \\
\text { District) }\end{array}$} & \multirow[t]{2}{*}{ Parasitism } & \multicolumn{3}{|l|}{ Parasite species } \\
\hline & & & & New species & $\begin{array}{l}\text { Previously } \\
\text { known species }\end{array}$ & $\begin{array}{l}\text { First/New } \\
\text { host } \\
\text { record }\end{array}$ \\
\hline \multirow[t]{6}{*}{12.} & $\begin{array}{l}\text { Wallago attu } \\
\text { (Bloch and } \\
\text { Schneider, 1801) }\end{array}$ & $\begin{array}{l}\text { Gerukamukh } \\
\text { (Lower } \\
\text { Subansiri) }\end{array}$ & + ive & & $\begin{array}{l}\text { Mizellius } \\
\text { indicus Jain, } \\
1957\end{array}$ & \\
\hline & (Demersal) & $\begin{array}{l}\text { Pasighat } \\
\text { (East Siang) }\end{array}$ & & & $\begin{array}{l}\text { Thaparocleidus } \\
\text { indicus } \\
\text { (Kulkarni, } \\
\text { 1969) Lim, } \\
1996\end{array}$ & \\
\hline & & & & & $\begin{array}{l}\text { Thaparocleidus } \\
\text { sudhakari } \\
\text { Gussev, } 1976\end{array}$ & \\
\hline & & & & & $\begin{array}{l}\text { Thaparocleidus } \\
\text { gomtius (Jain, } \\
\text { 1952) Lim, } \\
\text { 1996 }\end{array}$ & \\
\hline & & & & & $\begin{array}{l}\text { Thaparocleidus } \\
\text { yogendrai } \\
\text { Agarwal, } 1981\end{array}$ & \\
\hline & Family: Sisoridae & & & & & \\
\hline \multirow[t]{2}{*}{13.} & $\begin{array}{l}\text { Creteuchilolansis } \\
\text { sp. }\end{array}$ & $\begin{array}{l}\text { Grangar } \\
\text { (Tawang) }\end{array}$ & - ive & - & & \\
\hline & (Benthopelagic) & & & & & \\
\hline \multirow[t]{2}{*}{14.} & $\begin{array}{l}\text { Creteuchiloglanis } \\
\text { kamengensis } \\
\text { (Jayram, 1966) }\end{array}$ & $\begin{array}{l}\text { Rupa (West } \\
\text { Kameng) }\end{array}$ & - ive & & & \\
\hline & (Benthopelagic) & & & & & \\
\hline \multirow[t]{2}{*}{15.} & $\begin{array}{l}\text { Gagata cenia } \\
\text { (Hamilton, 1822) }\end{array}$ & $\begin{array}{l}\text { Dikrong } \\
\text { (Papumpare) }\end{array}$ & + ive & $\begin{array}{l}\text { Thaparocleidus } \\
\text { sp. n. } 3\end{array}$ & & First \\
\hline & (Demersal) & & & & & \\
\hline \multirow[t]{2}{*}{16.} & $\begin{array}{l}\text { Glyptothorax cavia } \\
\text { (Hamilton, 1822) }\end{array}$ & $\begin{array}{l}\text { Dikrong } \\
\text { (Papumpare) }\end{array}$ & + ive & $\begin{array}{l}\text { Bychowskyella } \\
\text { sp. n. } 1\end{array}$ & & First \\
\hline & (Demersal) & & & & & \\
\hline \multirow[t]{2}{*}{17.} & $\begin{array}{l}\text { Glyptothorax } \\
\text { dikrongensis } \\
\text { (Tamang \& } \\
\text { Chaudhry, 2011) }\end{array}$ & $\begin{array}{l}\text { Dikrong } \\
\text { (Papumpare) }\end{array}$ & + ive & $\begin{array}{l}\text { Bychowskyella } \\
\text { sp. n. } 3\end{array}$ & & First \\
\hline & (Demersal) & & & & & \\
\hline
\end{tabular}




\begin{tabular}{|c|c|c|c|c|c|c|}
\hline \multirow{2}{*}{$\begin{array}{l}\text { S. } \\
\text { No. }\end{array}$} & \multirow{2}{*}{$\begin{array}{l}\text { Fish sampled } \\
\text { (Habitat) }\end{array}$} & \multirow{2}{*}{$\begin{array}{l}\text { Sampling } \\
\text { site } \\
\text { (River basin, } \\
\text { District) }\end{array}$} & \multirow[t]{2}{*}{ Parasitism } & \multicolumn{3}{|l|}{ Parasite species } \\
\hline & & & & New species & $\begin{array}{l}\text { Previously } \\
\text { known species }\end{array}$ & $\begin{array}{l}\text { First/New } \\
\text { host } \\
\text { record }\end{array}$ \\
\hline \multirow[t]{2}{*}{18.} & $\begin{array}{l}\text { Glyptothorax } \\
\text { mibangi (Darshan, } \\
\text { Dutta, Kachari and } \\
\text { Das 2015) }\end{array}$ & $\begin{array}{l}\text { Dikrong } \\
\text { (Papumpare) }\end{array}$ & + ive & $\begin{array}{l}\text { Bychowskyella } \\
\text { sp. n. } 2\end{array}$ & & First \\
\hline & (Demersal) & & & & & \\
\hline \multirow[t]{3}{*}{19.} & $\begin{array}{l}\text { Nangra } \\
\text { assamensis (Sen } \\
\text { and Biswas, 1994) }\end{array}$ & $\begin{array}{l}\text { Dikrong } \\
\text { (Papumpare) }\end{array}$ & - ive & - & & \\
\hline & (Demersal) & & & & & \\
\hline & Family: Schilbeidae & & & & & \\
\hline \multirow[t]{3}{*}{20.} & $\begin{array}{l}\text { Pachypterus } \\
\text { atherinoides } \\
\text { (Bloch, 1794) }\end{array}$ & $\begin{array}{l}\text { Dikrong } \\
\text { (Papumpare) }\end{array}$ & - ive & - & & \\
\hline & (Demersal) & & & & & \\
\hline & Family: Olyridae & & & & & \\
\hline \multirow[t]{2}{*}{21.} & $\begin{array}{l}\text { Olyra longicaudata } \\
\text { (McClelland, 1842) }\end{array}$ & $\begin{array}{l}\text { Dikrong } \\
\text { (Papumpare) }\end{array}$ & - ive & - & & \\
\hline & (Demersal) & & & & & \\
\hline
\end{tabular}

Due to technical limitations, table 2 is only available as a download in the Supplemental Files section.

\section{Figures}

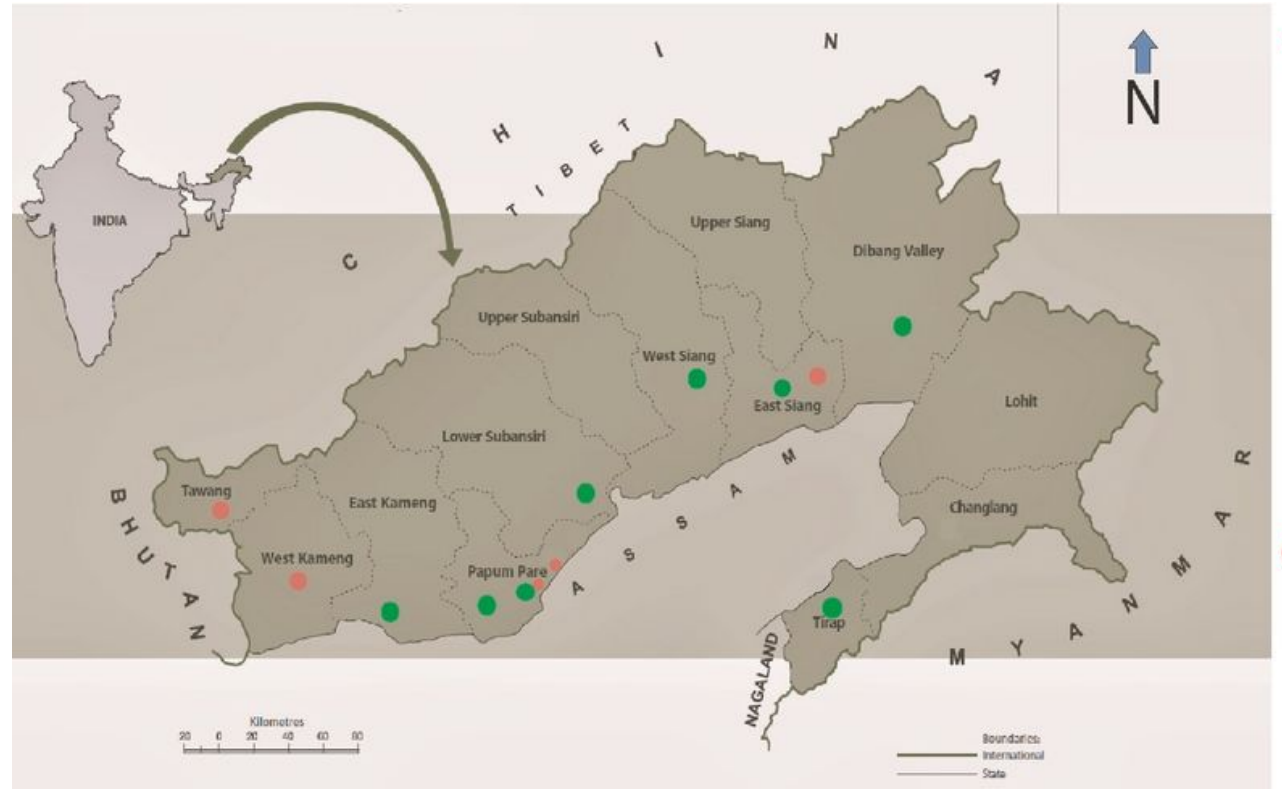

POSITIVE SAMPLES

Amblyceps arunachalensis(Nath and Dey, 1989)

Batasio batasio (Hamilton, 1822)

Batasio fasciolatus (Ng, 2006)

Gagata cenia(Hamilton, 1822)

Glyptothorax mibangi(Darshan, Dutta, Kachari and Das 2015)

Glyptothorax cavia(Hamilton, 1822)

Glyptothorax dikrongensis (Tamang \& Chaudhry, 2011)

Mystus bleekeri (Day, 1877)

Mystus tengara (Hamilton, 1822)

Mystus dibrugarensis (Chaudhuri, 1913)

Ompok pabda (Hamilton, 1822)

Pseudolaguvia viriosa (Ng \& Tamang, 2012)

Pterocryptus indicus (Datta, Barman \& Jayaram, 1987)

Sperata aor(Hamilton, 1822)

Wallago attu(Bloch and Schneider, 1801)

NEGATIVE SAMPLES

Creteuchilolansis kamengensis (Jayaram, 1966)

Creteuchilolansis sp.

Heteropneusteus fossilis (Bloch, 1794)

Nangra assamensis (Sen and Biswas, 1994)

Olyra longicaudata (McClelland, 1842)

Pachypterus antherinoides (Bloch, 1794) 


\section{Figure 1}

Map of sampling sites in Arunachal Pradesh, India corresponding to the following seven major river basins: Dibang, Dikrong, Kameng, Siang, Subansiri, Tawang, and Tirap-Dehing

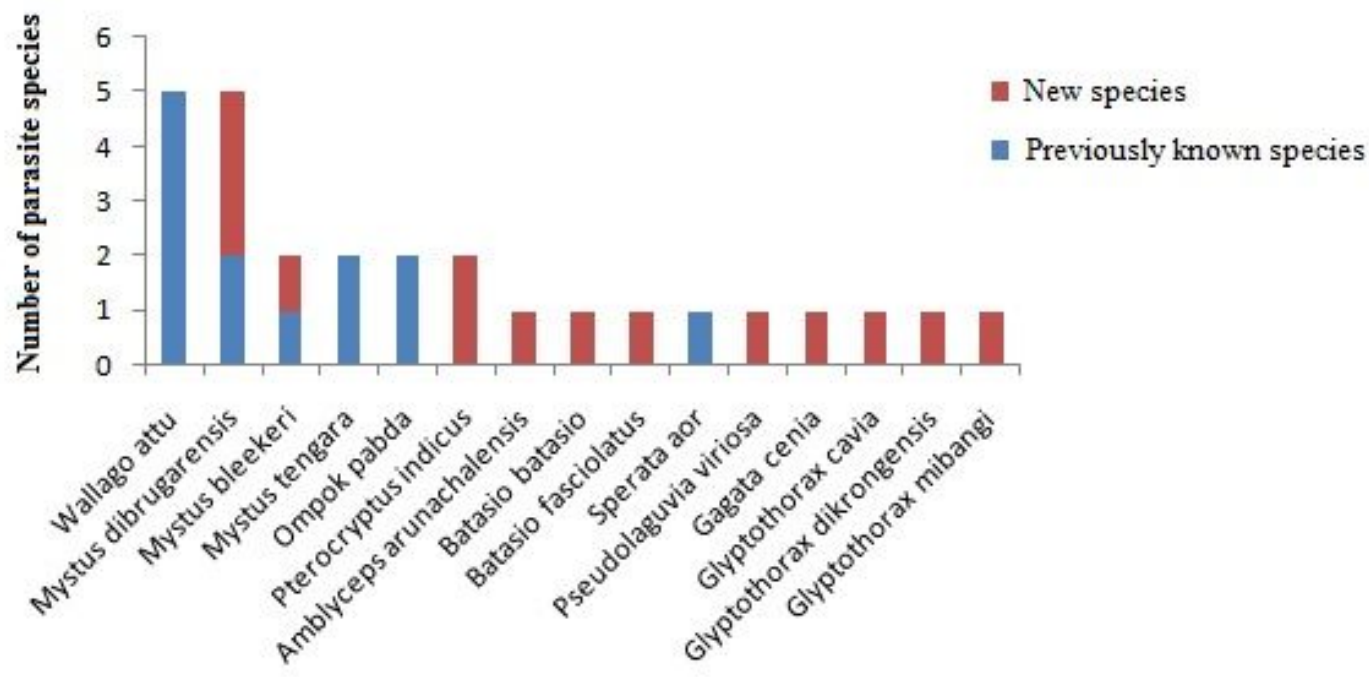

\section{Catfishes (Siluriformes )}

\section{Figure 2}

Species diversity of monogenoids from catfishes examined in Arunachal Pradesh
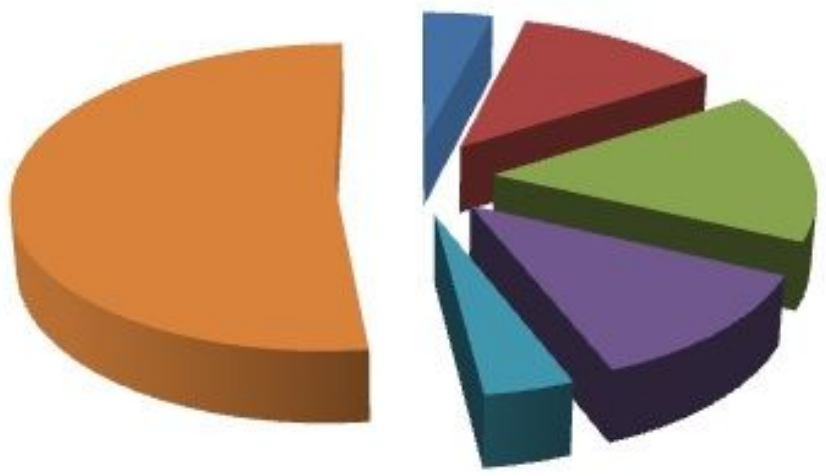

$$
\begin{aligned}
& \text { - Bifurcohaptor (1 species) } \\
& \text { - Bychowskyella (3 species) } \\
& \text { - Cornudiscoides (4 species) } \\
& \text { - Gyrodactylus (3 species) } \\
& \text { - Mizelleus (1 species) } \\
& \text { - Thaparocleidus (13 species) }
\end{aligned}
$$

\section{Figure 3}




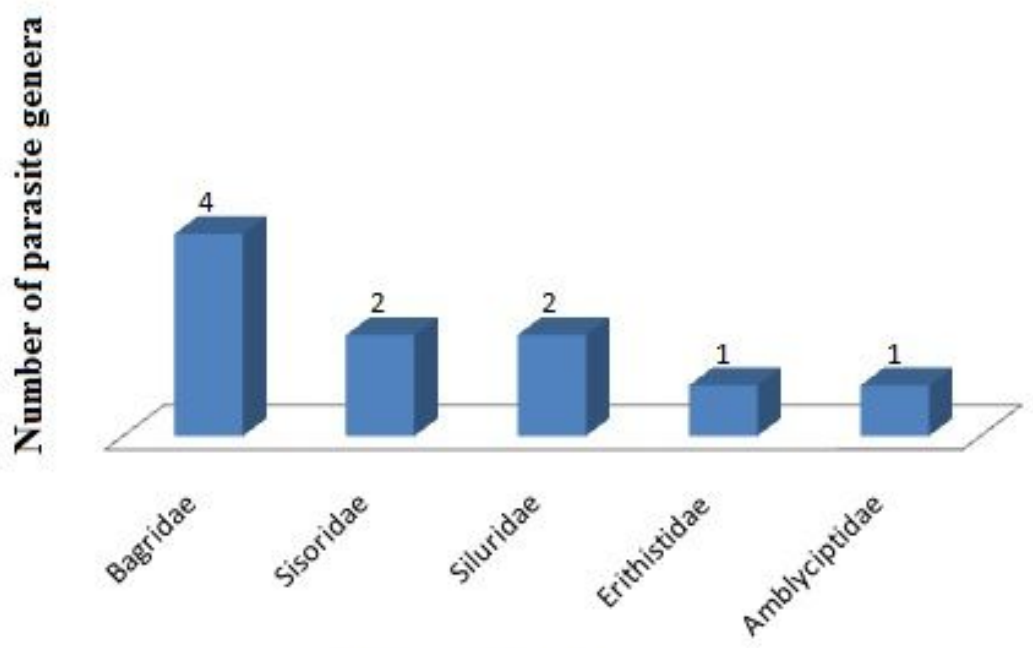

\section{Catfishes ( Siluriformes)}

\section{Figure 4}

Most parasitised catfish family in Arunachal Pradesh

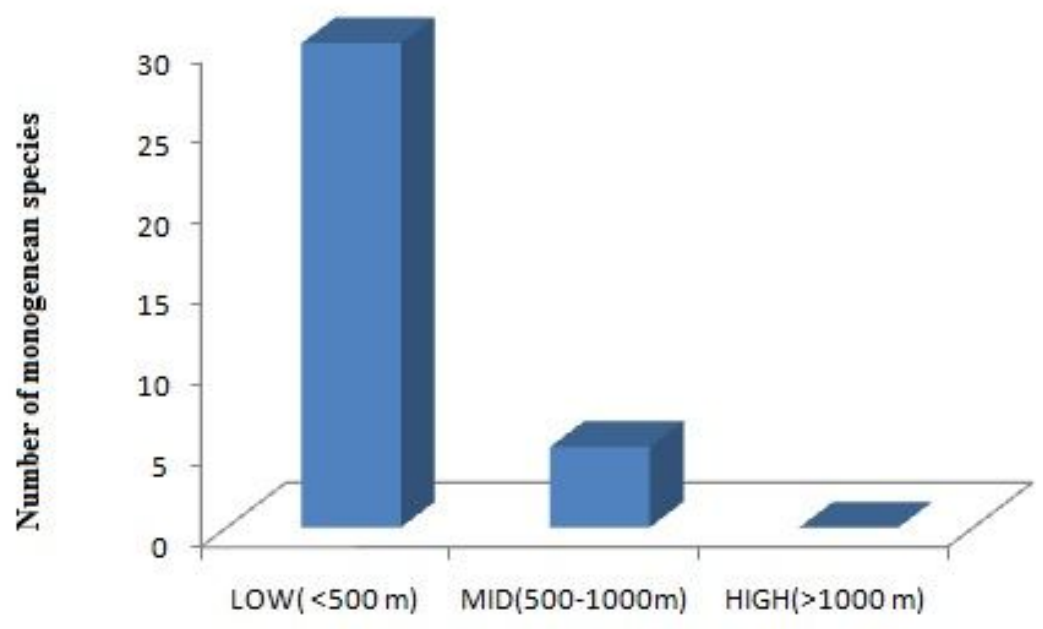

Altitude (Elevation in metres above sea level)

\section{Figure 5}

Distribution of monogenoids in relation to altitude (elevation in metres above sea level)

\section{Supplementary Files}


This is a list of supplementary files associated with this preprint. Click to download.

- Table2.jpg 